> Gi respons på artikler gjennom artiklenes kommentarfelt på tidsskriftet.no.

Innleggene publiseres fortløpende på Tidsskriftets nettside og et utvalg

av innleggene publiseres også i papirutgaven i spalten «Brev til redaktøren».

Redaksjonen forbeholder seg retten til å foreta redaksjonelle endringer.

Forfattere av vitenskapelige artikler har tilsvarsrett, jf. Vancouver-gruppens regler.

\section{Re: Tvilsom begrunnelse for reservasjonsmulighet}

Andreas Eriksen hevder at den typen moralsk integritet som reservasjonsadgang vil beskytte, «er en passiv versjon av integritet som først og fremst handler om å beskytte aktørens selvbilde» (1). Dette mener jeg ikke er riktig.

Reservasjon har tre viktige hensikter: Reservasjonslegen slipper å gjøre noe som oppfattes som alvorlig galt, hun/han får unnlate å skade en tredjeperson, fosteret, og hun/han får beskytte egen integritet (2). Konsistens og moralsk integritet kan fordre aktive handlinger også, slik som politisk stemmegivning, men legekontoret er ikke arenaen for dette.

Videre skriver Eriksen: «Man er (...) allerede medvirkende til drap ved å ha en rolle i en institusjon som utfører disse drapene.» Dette synet er problematisk. Er en gynekolog virkelig medansvarlig for at det utføres aborter, når hun/han selv aktivt har reservert seg og dermed tatt avstand? Innebærer det å betale skatt tilslutning til, og medansvar for, alt staten bruker pengene på? Naturrettstradisjonen har et velutviklet rammeverk for å vurdere moralsk betydning av samarbeid med uetiske handlinger (3). Det identifiserer viktige vesens- og gradsforskjeller.

Ifølge naturretten er handlingens intensjon spesielt viktig. Eriksen kritiserer påstanden om at å henvise kan oppleves som å stille seg bak pasientens intensjon om abort. «Leger trenger på ingen måte dele pasientens moralske valg om å ta abort», skriver han. Her legger han til grunn noe jeg synes er et problematisk intensjonsbegrep. Ifølge naturrettstradisjonen er intensjon en mental tilstand som resulterer i handling (4). Intensjonen er ikke det vi skulle ønske ville skje, men det vi faktisk velger. I intensjonen inngår både handlingens formål og midler. I denne forståelsen er aborthenvisning nettopp å velge abort - å henvise innebærer logisk å «gi ordre om» det som det henvises til. Én reservasjonslege beskrev aborthenvisning som «å signere en dødsdom» (5). Selv om dette synet kan utfordres av konkurrerende forståelser, bygger det på et filosofisk fundament. Det taler for at samvittighetsoverbevisningene som springer ut av dette synet, bør tolereres.

Jeg får inntrykk av at Eriksen mener leger trygt kan legge vekk sin egen etiske refleksjon og lojalt følge staten i alt. Men dette er farlig, slik Charlotte Haug viser med eksempel fra Kinas ettbarnspolitikk (6). En konsekvens av Eriksens syn er at leger må pålegges å utføre eller henvise til eutanasi hvis dette en gang blir tillatt.

Kunne vi få til en kultur for å tolerere hverandres syn i viktige etiske spørsmål? Da ville vi ha en viktig etisk beredskap neste gang medisinen blir fristet til å begå etiske feiltrinn. Slik jeg ser det, finnes det i grunn bare to alternativer: Enten tar staten avgjørelsene i etiske kontroverser og dikterer legenes praksis, eller så regnes legen som en selvstendig moralsk handlende, som må stå til regnskap overfor egen samvittighet, kolleger og samfunn. Det siste er i det lange løp å foretrekke - også for pasientene (7).

\section{Morten Magelssen}

magelssen@gmail.com

Morten Magelssen (f. 1978) er ph.d.-stipendiat.

Ingen oppgitte interessekonflikter

\section{Litteratur}

1. Eriksen A. Tvilsom begrunnelse for reservasjonsmulighet. Tidsskr Nor Legeforen 2014; 134: 505-6.

2. Magelssen M. Menneskeverd i klinikk og politikk. Bioetikk i lys av kristen tro. Oslo: Lunde Forlag, 2013.
3. Sulmasy DP. What is conscience and why is respect for it so important? Theor Med Bioeth 2008; 29: 135-49.

4. Finnis J, Grisez G, Boyle J. «Direct» and «indirect»: a reply to critics of our action theory. Thomist 2001; 65: 1-44.

5. Nordberg EMK, Skirbekk H, Magelssen M. Conscientious objection to referrals for abortion: pragmatic solution or threat to women's rights? BMC Med Ethics 2014; 15: 15

6. Haug C. Dilemmaenes århundre. Tidsskr Nor Legeforen 2014; 134: 493

7. Haaland E. Et gode for pasient, samfunn og demokrati. Aftenposten 21.2.2014. http://aftenposten.no/meninger/kronikker/Et-gode-for-pasient_-samfunn-ogdemokrati-7475619.html (18.3.2014).

\section{A. Eriksen svarer:}

Ut fra dette innlegget kan det se ut som om Morten Magelssen har skiftet syn på integritet. Magelssen er medforfatter av notatet fra Civita (1) jeg diskuterer i kommentarartikkelen Tvilsom begrunnelse for reservasjonsmulighet, og der står det at reservasjonen beskytter integritet forstått som «ubrutt helhet»- man bevarer sitt moralske selvbilde i jobben (1, s 6). I sin kommentar til min artikkel hevder Magelssen at min tolkning av dette som en passiv versjon av integritet, som først og fremst handler om å beskytte aktørens selvbilde, er uriktig. Integritet «kan fordre aktive handlinger også», men «legekontoret er ikke arenaen for dette». Hva har denne integritetsforståelsen da med legers reservasjon å gjøre?

Videre hevder Magelssen at aktører som har en rolle i en institusjon, ikke trenger å ta medansvar for handlinger som utføres i institusjonens navn. Man kan reservere seg mot «uakseptable og dypt umoralske» drap $(1, \mathrm{~s} 7)$ og uten medansvar la kolleger gjøre det. Igjen, hvis dette er å utøve integritet, mener jeg det framstår som en betenkelig dygd.

Magelssen argumenterer mot begrepet medansvar med at vi som borgere ikke har ansvar for hva staten bruker skattepengene på. Men dersom den norske stat brukte skattepengene mine på et moralsk forkastelig vis, ville det ikke vært unaturlig av meg å ta ansvar i form av protest og sivil ulydighet. Og ansvaret ville vært betydelig dersom jeg representerte institusjonen som faktisk gjennomførte det umoralske, da min rolle i større grad støtter handlingene.

Jeg skriver at leger ikke trenger å dele den enkelte pasients valg om abort. De deler profesjonens intensjon om å gi pasienten rettmessig hjelp. Her opererer jeg ifølge Magelssen med et problematisk intensjonsbegrep. Han mener at vi kan slutte fra legens betydelige bidrag i årsakskjeden til at legen deler pasientens intensjon om abort $(1$, s 6$)$. I så fall deler f.eks. advokater som forsvarer ytringsfrihet sine klienters intensjoner om trusler. Men å oppfylle rettigheter er ikke det samme som å støtte den konkrete handlingen som rettighetene er et middel til.

Magelssen har fått inntrykk av at jeg mener at leger bør følge staten $i$ alt. I virkeligheten angriper jeg tanken om at profesjonsrollen alltid gir moralsk belegg for handling. Bare legitime rolleinstrukser begrunner handling. Legitimitet har en nedre moralsk terskel. Terskelen markerer overgangen fra rimelig uenighet til forakt for moralprinsipper. Autoritære regimers politikk er altså ikke noe motargument mot det jeg skriver.

Mitt syn har ifølge Magelssen den konsekvens at leger må pålegges å utføre eller henvise til eutanasi hvis dette blir tillatt. Det er underlig, for jeg argumenterer jo ikke for at leger må pålegges dette i abortspørsmål. Istedenfor skriver jeg: «Samfunnet må ta stilling til hvorvidt samvittighetsfriheten kan institusjonaliseres i ulike offentlige roller uten at den blir en urimelig byrde for pasientene.»

Men institusjonalisering av rettigheter er uansett ikke ønskelig, hevder Magelssen. Han vil at legen skal regnes som «selvstendig 
moralsk handlende». Her forkastes ideen om legerollen som tillitsverdig uavhengig av hvem som sitter på kontoret. Slike premisser gjør ikke begrunnelsen for reservasjonsadgang mindre tvilsom.

\section{Andreas Eriksen}

andreas.eriksen@hioa.no

Andreas Eriksen (f. 1984) har en mastergrad i filosofi og er ph.d.-stipendiat ved Senter for profesjonsstudier, Høgskolen i Oslo og Akershus. Ingen oppgitte interessekonflikter.

\section{Litteratur}

1. Clemet K, Magelssen M, Jørgensen HN. Samvittighetsfrihet og fastlegers reservasjonsrett. Civita-notat nr. 17/2012, i samarbeid med Tankesmien Skaperkraft. Oslo: Civita, 2012.

\section{Re: Sjeldenhet - eget kriterium ved prioritering?}

Heiberg og medarbeidere mener at sjeldenhet av sykdommen bør være et eget kriterium ved prioritering i helsevesenet (1). Det mener jeg er en avsporing av en viktig debatt. Sjeldenhet har egenverdi bare for samlere, f.eks. av sommerfugler og frimerker. I helsevesenet driver man, forhåpentlig, ikke med samling. At sykdommen er sjelden har ikke betydning i seg selv, til forskjell fra sykdommens alvorlighetsgrad og nytte av eventuell behandling.

Sakens kjerne er vektlegging av kostnader ved behandling. Heiberg og medarbeidere har som etisk premiss at ved prioritering bør alle ha «like muligheter til helse», dvs. også om det er variasjon i kostnadene. Tiltak for personer med sjeldne sykdommer tenderer til å være svært kostbare regnet per person. Det følger at det offentlige helsevesen bør være innstilt på å akseptere høyere kostnader per vunnet QALY i forbindelse med sjeldne sykdommer enn i forbindelse med vanlige sykdommer. Men av det etiske premisset om like behandlingsmuligheter for alle følger det like mye at personer som er dyre å behandle av andre grunner enn sjeldenhet, bør tilgodeses med høyere betalingsvillighet per QALY. Skal man ha større betalingsvillighet i forbindelse med personer som er dyre pga. sjeldenhet, enn i forbindelse med personer som er dyre av andre grunner, må man ha en god grunn. Dette problemet overser Heiberg og medarbeidere.

En australsk-norsk studie tydet på at folk flest synes at kostnader ikke bør tillegges så stor vekt som prioritering etter kostnad-nytteforhold tilsier (2). Dette er et viktig tema å diskutere. Ut av det kan det komme konklusjoner som er gunstige også for personer med sjeldne sykdommer. Men det betyr altså ikke at sjeldenhet fortjener å bli eget prioriteringskriterium.

Ellers synes jeg at forfatternes omgang med QALY-begrepet er forvirrende. QALY er et uttrykk for størrelsen på helsegevinster, ikke for samfunnsmessig verdsettelse av tiltak for ulike grupper (3). I det sistnevnte kommer rettferdighetsbetraktninger inn i bildet. Det er per i dag å slå inn nokså åpne dører å si at det offentlige helsevesenets betalingsvillighet for en QALY vil måtte avhenge av omstendighetene (4).

\section{Erik Nord}

erik.nord@fhi.no

Erik Nord (f. 1948) er professor i helseøkonomi, Nasjonalt folkehelseinstitutt/Universitetet i Oslo.

Ingen oppgitte interessekonflikter

\section{Litteratur}

1. Heiberg A, Frich J, Røttingen JA. Sjeldenhet - eget kriterium ved prioritering? Tidsskr Nor Legeforen 2014; 134: 534-6.

2. Nord E, Richardson J, Street A et al. Who cares about cost? Does economic analysis impose or reflect social values? Health Policy 1995; 34: 79-94.

3. Nord E, Richardson J, Macarounas-Kirchmann K. Social evaluation of health care versus personal evaluation of health states. Evidence on the validity of four health-state scaling instruments using Norwegian and Australian surveys. Int J Technol Assess Health Care 1993; 9: 463-78.

4. Økonomisk evaluering av helsetiltak - en veileder. Oslo: Helsedirektoratet, 2012.

\section{A. Heiberg og medarbeidere svarer:}

I sitt kommentarinnlegg er Nord uenig $i$ at status som sjelden diagnose bør tillegges vekt ved prioriteringer i helsevesenet, og han hevder at vi misforstår QALY-begrepet. I vår artikkel skrev vi: «Gjennom størrelsen «kvalitetsjusterte leveår» (QALY) kan man få et mål for hvordan befolkningen verdsetter et ekstra leveår for en person i gruppe A og en person i gruppe B, og man vil kunne legge dette til grunn når man skal prioritere».

La oss presisere at vi med «verdsetter» i sitatet over viser til hvordan respondenter i en befolkning verdsetter kvaliteten på livet med en gitt tilstand eller sykdom på en skala fra 0,0 til 1,0. En av hensiktene med vår artikkel var å påpeke at dersom man ensidig innfører en øvre grense for behandlingskostnader basert på QALY, vil personer med sjeldne sykdommer i praksis ekskluderes fra muligheten til likeverdig behandling.

Nord skriver: «Men av det etiske premisset om like behandlingsmuligheter for alle følger det like mye at personer som er dyre å behandle av andre grunner enn sjeldenhet, bør tilgodeses med høyere betalingsvillighet». Vi er, som vi sier i artikkelen, enige i at det kan være andre forhold, slik som en sykdoms alvorlighet, som kan begrunne høyere betalingsvillighet for tilstander som ikke er sjeldne.

Nord etterlyser argumentasjon for at sjeldenhet er relevant som eget kriterium i en prioriteringssammenheng. Hovedargumentet i vår artikkel er: Det er en kjensgjerning at utviklings- og innovasjonskostnadene for legemidler til pasientgrupper med sjeldne sykdommer ikke er lavere enn for andre sykdommer. I og med at slike kostnader må fordeles på et færre antall pasienter, vil dette gjenspeiles i prisen på behandlingen. Det vil følgelig, som hovedregel, koste mer for samfunnet å behandle en pasient med en sjelden diagnose sammenliknet med en pasient med en vanligere sykdom.

De internasjonale ordningene for «orphan diseases» $(1,2)$ tar høyde for at utviklings- og innovasjonskostnadene for sjeldne tilstander må dekkes inn på et færre antall pasienter, og de forsøker å korrigere denne markedssvikten for å sikre likeverdige behandlingsmuligheter. Dette kan gjøres ved raskere og enklere godkjenningsprosesser, lengre markedseksklusivitet og signaler om villighet til høyere pris. Disse mekanismene er etablert politikk og praksis i Norge, Europa og USA, og viser at sjeldenhet implisitt er etablert som de facto prioriteringskriterium. Vårt poeng er at sjeldenhet også formelt bør gis en slik status slik at vi sikrer dem med sjeldne sykdommer en lik rett til behandlingsmuligheter.

\section{Arvid Heiberg \\ arvhei@ous-hf.no \\ Jan Frich}

\section{John-Arne Røttingen}

Arvid Heiberg (f. 1937) er professor og tidligere overlege ved Avdeling for medisinsk genetikk, Oslo universitetssykehus, Rikshospitalet, og medlem av nasjonal forskningsetisk komité for medisin.

Oppgitte interessekonflikter: Han har deltatt i møter arrangert av BioMarin, Genzyme og Shire og utfører forskning med henblikk på pasienter med Huntingtons sykdom, finansiert av CHDI (Cure Huntington's Disease Initiative), en USA-basert forskningsstiftelse.

Jan Frich (f. 1970) er professor ved Avdeling for helseledelse og helse$\emptyset$ konomi, Universitetet i Oslo, og overlege ved Nevrologisk avdeling, Oslo universitetssykehus.

Oppgitte interessekonflikter: Han er involvert i forskningsprosjekter om Huntingtons sykdom, inkludert studiene REGISTRY/Enroll-HD og en PET-studie av fosfodiesterase 10A, finansiert av CHDI Foundation.

John-Arne Røttingen (f. 1969) er prosjektleder for HelseOmsorg 21, divisjonsdirektør ved Nasjonalt folkehelseinstitutt og professor ved Avdeling for helseledelse og helseøkonomi, Universitetet i Oslo.

Ingen oppgitte interessekonflikter. 